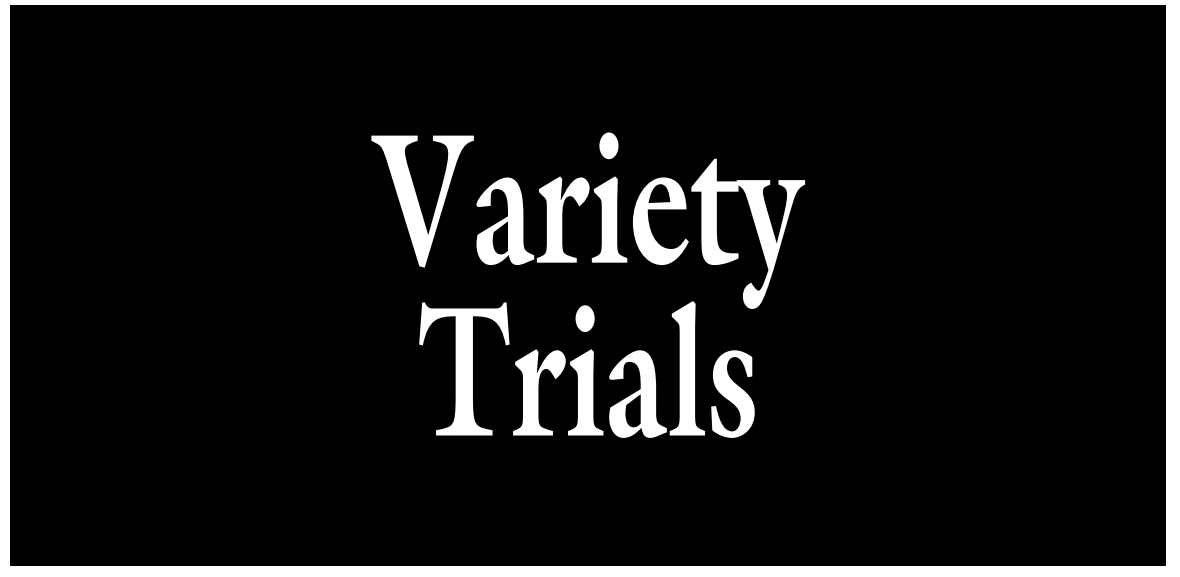

\section{Performance and Quality of Sweetpotato Cultivars Grown in Quebec, Canada with Biodegradable Plastic Mulch}

\author{
David Wees ${ }^{1,3}$, Philippe Seguin ${ }^{1}$, Josée Boisclair ${ }^{2}$, and \\ Chloé Gendre ${ }^{1}$
}

ADDITIONAL INDEX WORDs. Ipomoea batatas, pesticide-free, organic, rooted cuttings, degree days, soluble solids

SUMMARY. There is an increased interest in producing sweetpotato (Ipomoea batatas) in parts of eastern Canada, which are farther north and have fewer growing degree days (GDD) than traditional production regions in the southern United States. There is currently little information on cultivar selection for farmers in these northern regions. We evaluated yields and quality of 15 sweetpotato cultivars and selected lines grown with black plastic mulch but without pesticides. The best marketable yields $\left(18-25 \mathrm{t} \cdot \mathrm{ha}^{-1}\right)$ in this trial were comparable to average marketable yields obtained in traditional sweetpotato-producing regions. Of the orange-fleshed cultivars and selected lines, Beauregard, B94-24, and Evangeline had high yields and warrant further testing. Covington, a common cultivar in North Carolina and Ontario, had poor yields in our conditions: it may require more GDD. 'Porto Rico' and 'Ginseng Red' had poor yields mainly because their storage roots were too small. The yellow-fleshed 'Georgia Jet' and GJ2010 had very vigorous vines and produced high yields, but had a high culling rate because of malformed or cracked storage roots. The white-fleshed 'Murasaki-29', 'O'Henry', and 'Japanese' also had high yields; whereas 'White Travis' and 'Korean Purple' had poor yields with small storage roots. Establishing the crop with rooted transplants instead of slips was satisfactory as long as the transplants were less than 4 weeks old. On the basis of our limited data, the following cultivars and selected lines may be suitable for Quebec, Canada: Beauregard, B94-24, Evangeline, Georgia Jet, GJ2010, and Murasaki-29. 'Evangeline' and 'Covington' had higher soluble solid contents than the other cultivars. High percent soluble solids may be desired by consumers. In spite of the absence of pesticides, very few pest or disease problems were observed except for some postharvest soft rot. and Rural Affairs (OMAFRA), 2010] compared with many other vegetables and because it currently has few diseases and pests in regions where sweetpotato is not widely grown. Indeed, sweetpotato is in a different plant family (Convolvulaceae) from most other crops, which may make it ideal for crop rotation in organic production systems. This may allow producers, including small-scale growers, to tap into local markets by selling sweetpotatoes in farmers' markets or through other forms of direct marketing.

Sweetpotato is one of the most important crops worldwide (Lebot, 2009). Currently, China is the leading producer with $\approx 70 \%$ of the World's annual crop of over 100 million tonnes (Food and Agriculture Organization of the United Nations, 2013). In North America, over $90 \%$ of production is concentrated in the southeastern United States (mainly North Carolina, Mississippi, and Louisiana) and in California [U.S. Department of Agriculture (USDA), 2011a]. Thus, most sweetpotatoes consumed in Canada and the northern tier of the United States are shipped long distances to reach these northern markets. Indeed, $\approx 70 \%$ of U.S. sweetpotato exports are destined for Canada (USDA, 2011a). Consumption of sweetpotatoes in North America has greatly increased over the past decade. In the United States, per capita consumption has increased from $4.7 \mathrm{lb}$ in 2003 to $6.4 \mathrm{lb}$ in $201 \mathrm{l}$ (USDA, 2011b). In Canada, consumption has doubled in the past 10 years reaching $1.4 \mathrm{~kg}$ per person per year in 2013 (Statistics Canada, 2014). North American consumers have an increased interest in the sweetpotato in part because of its nutritional value: it is a good source of beta-carotene and
$\mathrm{T}$ There is an increased interest among North American consumers for locally grown foods, including organic produce and specialty, heirloom or "ethnic" vegetables. Some farmers seek to fill the demand created by these niche markets, but in some cases must compete with similar products grown elsewhere. Sweetpotato has potential for low-input or organic production to supply local markets, because of low nitrogen $(\mathrm{N})$ fertilizer requirements [Ontario Ministry of Agriculture, Food

\begin{tabular}{llll}
\hline $\begin{array}{l}\text { Units } \\
\begin{array}{l}\text { To convert U.S. to SI, } \\
\text { multiply by }\end{array}\end{array}$ & U.S. unit & SI unit & $\begin{array}{l}\text { To convert SI to U.S., } \\
\text { multiply by }\end{array}$ \\
\hline 0.3048 & $\mathrm{ft}$ & $\mathrm{m}$ & 3.2808 \\
2.54 & inch $(\mathrm{es})$ & $\mathrm{cm}$ & 0.3937 \\
25.4 & inch $(\mathrm{es})$ & $\mathrm{mm}$ & 0.0394 \\
16.3871 & inch & $\mathrm{cm}$ & 0.0610 \\
0.4536 & $\mathrm{lb}$ & $\mathrm{kg}$ & 2.2046 \\
1.1209 & $\mathrm{lb} / \mathrm{acre}$ & $\mathrm{kg} \cdot \mathrm{ha}{ }^{-1}$ & 0.8922 \\
0.0254 & $\mathrm{mil}$ & $\mathrm{mm}$ & 39.3701 \\
1.6093 & $\mathrm{mile}(\mathrm{s})$ & $\mathrm{km}$ & 0.6214 \\
28.3495 & $\mathrm{oz}$ & $\mathrm{g}$ & 0.0353 \\
7.4892 & $\mathrm{oz} / \mathrm{gal}$ & $\mathrm{g} \cdot \mathrm{L}^{-1}$ & 0.1335 \\
0.9072 & ton $(\mathrm{s})$ & $\mathrm{tonne}(\mathrm{s})$ & 1.1023 \\
2.2417 & ton $(\mathrm{s}) / \mathrm{acre}$ & $\mathrm{t} \cdot \mathrm{ha}$ & 0.4461 \\
$\left({ }^{\circ} \mathrm{F}-32\right) \div 1.8$ & ${ }^{\circ} \mathrm{F}$ & ${ }^{\circ} \mathrm{C}$ & $\left({ }^{\circ} \mathrm{C} \times 1.8\right)+32$
\end{tabular}

Hortlechnology · December 2015 25(6) 
dietary fiber and has a low glycemic index (Bovell-Benjamin, 2007; Lebot, 2009).

Currently, there is little sweetpotato production in areas with cool temperate climates such as Canada or the northern United States. Indeed, this crop requires a long, hot growing season to achieve maximum yields (Lebot, 2009). To compensate for the cooler, shorter growing season in Canada and the northern United States, growers may adopt some or all of the following strategies: using black plastic mulch, planting rooted cuttings, or choosing early-maturing cultivars.

In the relatively cool climates of Croatia (Novak et al., 2007) and Massachusetts (Hochmuth and Howell, 1983), the use of black plastic mulches significantly increased marketable yields of sweetpotato because of increased soil temperatures. Eguchi et al. (1994) found that yields of sweetpotato were higher at soil temperatures of $24^{\circ} \mathrm{C}$ than at 20 or $22^{\circ} \mathrm{C}$. Mulches also have the added advantage of suppressing weed growth. One disadvantage is that the mulch must be removed before harvest, but this problem can be circumvented by using biodegradable mulch that will at least partially decompose before harvest.

Sweetpotato can be propagated by planting rooted cuttings or "plugs" instead of the more commonly used unrooted "slips." Bornt (2012) in New York State and Novak et al. (2007) in Croatia found that using rooted cuttings or transplants instead of slips led to higher yields and larger storage roots. The larger initial root mass on rooted cuttings may encourage faster early growth compared with that obtained with slips (Novak et al., 2007).

Sweetpotato cultivars vary widely in terms of their yield and required length of growing season,

\footnotetext{
This research was supported by the Quebec Ministry of Agriculture's "Programme de soutien à l'innovation horticole" (project PSIHI1-2-548).

We thank Michael Bleho for technical assistance and also thank "La Ferme Onésime Pouliot" (Saint-Jean-de-l'Île d'Orléans, QC, Canada) for help in obtaining several of the cultivars tested and Carya Farm (Senneville, QC, Canada) for slips of Covington.

${ }^{1}$ Department of Plant Science, Faculty of Agricultural and Environmental Sciences, Macdonald Campus, McGill University, Sainte-Anne-de-Bellevue, QC H9X 3V9, Canada

${ }^{2}$ Institut de recherche et de développement en agroenvironnement, Saint-Bruno-de-Montarville, QC J3V 0G7, Canada

${ }^{3}$ Corresponding author. E-mail: david.wees@mcgill.ca.
}

which ranges from 3 to 6 months (Lebot, 2009; OMAFRA, 2010). 'Beauregard', 'Evangeline', 'Georgia Jet', 'Ginseng Red', and 'O'Henry' may be considered early maturing $(90-100 \mathrm{~d})$ according to the Sand Hill Preservation Center (2015). It should be noted that sweetpotato does not have a specific maturity date as the plant and its storage roots grow indeterminately as long as growing conditions are adequate (Lebot, 2009). Beauregard (Rolston et al., 1987) was the most widely grown cultivar in North America; although recently, Covington (Yencho et al., 2008) has become more popular in North Carolina. Most cultivar trials in North America have been conducted in the main sweetpotato growing areas which have long, hot growing seasons (National Sweetpotato Collaborators Group, 2012) although a few trials have been conducted in Ontario (Filotas, 2012), New Hampshire (Sideman, 2013), New York State (Bornt, 2012), and the Maritime Provinces of Canada (Zvalo et al., 2012). However, to our knowledge, there are no peerreviewed reports of commercial cultivar trials conducted in eastern North America north of the 45th parallel. Cultivar recommendations for cool environments in North America vary. In Ontario, 'Beauregard' and 'Covington' are recommended (OMAFRA, 2010). In New Hampshire, Grube (2009) suggested 'Beauregard', 'Covington', 'Georgia Jet', 'Japanese Yam', and possibly 'O'Henry' and 'Carolina Ruby'. In New York State, Bornt (2012) reported that in 2010 Georgia Jet was the most common cultivar, followed by Beauregard; but a subsequent survey in 2012 found that Beauregard and Covington had become the most common.

The goal of this project was to assess the potential yields and quality of sweetpotato grown in a cool, temperate climate, located in eastern Canada much farther north than traditional production areas, in a pesticide-free production system using black plastic mulch and rooted transplants. Although not completely organic, our test site has been certified by Local Food Plus (Land Food People Foundation, 2014) since 2011 , which limits the use of certain inputs such as pesticides. We also evaluated the yields and quality of 15 sweetpotato cultivars and selected lines including common orangefleshed types, some heirloom cultivars, and some specialty types with yellow or white flesh. Although less well known among North American consumers, yellow and white cultivars may present market opportunities (Leksrisompong et al., 2012). Finally, we wanted to observe which pests and diseases would develop in the absence of pesticides.

\section{Materials and methods}

In 2011 and 2012, field trials were performed at the Horticultural Research Center at the Macdonald Campus of McGill University, located in Sainte-Anne de Bellevue, QC, Canada (lat. $45^{\circ} 26^{\prime} \mathrm{N}$, long. $73^{\circ} 56^{\prime} \mathrm{W}$, altitude $39 \mathrm{~m}), \approx 30 \mathrm{~km}$ west of Montreal. The preceding crops were pumpkin (Cucurbita pepo) in 2011 and tomato (Solanum lycopersicum) in 2012. The soil, a St-Bernard loam, was very fertile with elevated phosphorus $\left(792 \mathrm{~kg} \cdot \mathrm{ha}^{-1} \mathrm{P}\right)$ and potassium (458 $\mathrm{kg} \cdot \mathrm{ha}^{-1} \mathrm{~K}$ ) as determined by Mehlich 3 soil test. It had received annual applications of compost made mainly with tree leaves and turfgrass clippings. Before planting, a 53-inchwide, 0.6-mm-thick, black, biodegradable, plastic mulch (Bionov B Mater-Bi ${ }^{\mathrm{TM}}$; Récoltech Accessoires Maraichers Inc, Saint-Rémi, QC, Canada) was laid on the experimental plots, which were on raised beds $\approx 15 \mathrm{~cm}$ high. This mulch was used to warm the soil and suppress weeds. In both years, the mulch had only partially degraded by harvest time and had to be removed before harvest. However, it was brittle and tore easily.

The cultivars and selected lines tested (Table 1) included eight with orange flesh (Beauregard, B94-24, Covington, Diane, Evangeline, Ginseng Red, Hernandez, and Porto Rico), two with yellow flesh (Georgia Jet and GJ2010), two with white flesh and tan skins (O'Henry and White Travis), and three "Asian" cultivars with purple skins and starchy white flesh (Korean Purple, Japanese, and Murasaki-29). The 'Georgia Jet' germplasm obtained from Mapple Farm (Weldon, NB, Canada) had yellow flesh rather than the orange flesh described by Harmon (1974). GJ2010 was propagated from a chance white-skinned mutant of 'Georgia Jet' found growing in our experimental plots in 2010. However, all storage roots produced from cuttings of this selection had pink skin and yellow flesh.

In 2011, five cultivars and selected lines were tested. Transplants 
Table 1. Flesh and skin colors, source, and origin of sweetpotato cultivars and selected lines evaluated in cultivar trials in Sainte-Anne-de-Bellevue, QC, Canada in 2011 and 2012.

\begin{tabular}{lllll}
\hline Cultivar or selected line & Flesh color & Skin color & $\begin{array}{c}\text { Source of } \\
\text { germplasm }\end{array}$ & \\
\hline $\begin{array}{l}\text { Beauregard } \\
\text { B94-24 }\end{array}$ & Orange & Copper & FT & Origin \\
Covington & Orange & Copper & LFP & Selected line of 'Beauregard' \\
Diane (MD-607) & Orange & Copper & CF & North Carolina (Yencho et al., 2008) \\
Evangeline & Orange & Red & LFP & Maryland \\
Ginseng Red & Orange & Copper & BF & Louisiana (La Bonte et al., 2008b) \\
$\begin{array}{l}\text { Hernandez } \\
\text { Porto Rico (N.C. Porto }\end{array}$ & Orange (light) & Copper & MF & Heirloom cultivar, origin unknown \\
$\quad$ Rico 198) & Orange (dark) & Orange & BF & Louisiana (La Bonte et al., 1992) \\
Georgia Jet & Copper & LFP & North Carolina, selected line of heirloom cultivar \\
GJ2010 & Yellow & Pink & MF & Porto Rico (Pope and Hoover, 1966) \\
Japanese & Yellow & Pink & HRC & Mutation of 'Georgia Jet' \\
Korean Purple & White & Purple & BF & Unknown \\
Murasaki-29 & White & Purple & MF & Unknown \\
O'Henry & White & Purple & LFP & Louisiana (La Bonte et al., 2008a) \\
& White & Tan & LFP & White mutation of 'Beauregard'; see 'Beauregard' \\
White Travis & & & above
\end{tabular}

${ }^{\mathrm{z} F T}=$ Ferme Tournesol, Les Cèdres, QC, Canada; LFP = Legget Farming Partnership, Nashville, NC; CF = Carya Farm, Senneville, QC, Canada; BF = Bone Farms, Nashville, NC; MF = Mapple Farm, Weldon, NB, Canada; HRC = McGill University Horticultural Research Center, Sainte-Anne-de-Bellevue, QC, Canada.

Table 2. Dates of procedures, length of growing season, cumulative growing degree days (GDD), and rainfall for sweetpotato cultivar trials in Sainte-Annede-Bellevue, QC, Canada for the growing seasons of 2011 and 2012.

\begin{tabular}{lrc}
\hline & 2011 & $\mathbf{2 0 1 2}$ \\
\hline Propagation of cuttings & $16 \mathrm{May}$ & 22 May \\
Installation of plastic mulch & $3 \mathrm{June}$ & 11 June \\
Planting date & $15 \mathrm{June}$ & 15 June \\
Foliage removal & $3 \mathrm{Oct}$. & 2 Oct. \\
Harvest date & 5 Oct. & 2 Oct. \\
Length of growing season $(\mathrm{d})^{\mathrm{z}}$ & 112 & 109 \\
GDD using mean temperature and base of $15.5^{\circ} \mathrm{C}^{\mathrm{z}, \mathrm{y}, \mathrm{x}}$ & 558 & 585 \\
GDD using mean temperature and base of $60^{\circ} \mathrm{F}^{\mathrm{z}, \mathrm{y}, \mathrm{x}}$ & 995 & 1,044 \\
GDD using maximum temperature and base of $60^{\circ} \mathrm{F}^{\mathrm{z}, \mathrm{y}, \mathrm{w}}$ & 1,904 & 1,995 \\
Cumulative rainfall $(\mathrm{mm})^{\mathrm{z}, \mathrm{y}}$ & 463.0 & 276.4 \\
\hline
\end{tabular}

${ }^{\mathrm{z}}$ Accumulated from planting until harvest.

$\mathrm{y}\left(1.8 \times{ }^{\circ} \mathrm{C}\right)+32={ }^{\circ} \mathrm{F}, 1 \mathrm{~mm}=0.0394$ inch.

$\times[($ maximum air temperature + minimum air temperature $) / 2]-$ base temperature, where base temperature is $15.5{ }^{\circ} \mathrm{C}$ or $60{ }^{\circ} \mathrm{F}\left(\mathrm{McM}\right.$ aster and Wilhelm, 1997); $\left({ }^{\circ} \mathrm{F}-32\right) \div 1.8={ }^{\circ} \mathrm{C}$.

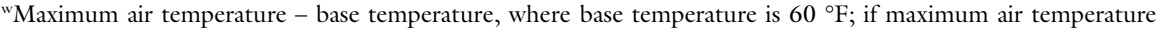
greater than $90^{\circ} \mathrm{F}$, then maximum air temperature was reset to $90^{\circ} \mathrm{F}$ (Villordon et al., 2009).

of 'Beauregard', 'Ginseng Red', 'Georgia Jet', GJ2010, and 'White Travis' were prepared by sprouting storage roots in a glass greenhouse [24/ $20{ }^{\circ} \mathrm{C}$ (day/night)]. Single-node cuttings were taken from the sprouts and rooted for 4 weeks in a peat-based substrate (Agromix PV20 ${ }^{\mathrm{TM}}$; Fafard \& Frères Ltée, Saint-Bonaventure, QC, Canada) in 98-plug trays $(54 \times 28 \mathrm{~cm})$ with square plugs, whose internal dimensions were $3.3 \times 3.3 \times 5 \mathrm{~cm}$ deep (Blackmore Co., Belleville, MI). Cuttings were fertilized weekly with $1 \mathrm{~g} \cdot \mathrm{L}^{-1}$ of $15 \mathrm{~N}-6.6 \mathrm{P}-14.9 \mathrm{~K}$ water-soluble fertilizer that also contained $0.15 \%$ magnesium $(\mathrm{Mg}), 0.1 \%$ iron $(\mathrm{Fe}), \quad 0.05 \%$ copper $(\mathrm{Cu}), 0.02 \%$ boron $(\mathrm{B}), 0.05 \%$ manganese $(\mathrm{Mn}), 0.05 \%$ zinc $(\mathrm{Zn})$, and 0.015\% molybdenum (Mo) (Plant Products, Ancaster, ON, Canada). Cuttings were placed outdoors a few days before transplanting to harden them off. See Table 2 for dates of propagation, planting, and harvesting.

In 2012, 15 cultivars and selected lines were tested. The five cultivars and selected lines previously tested in 2011 (Beauregard, Ginseng Red, Georgia Jet, GJ2010, and White Travis) were propagated by singlenode cuttings taken from sprouted sweetpotatoes planted in a greenhouse. The cuttings were rooted for 3 weeks in 98-plug trays starting on 22 May 2012. Slips of the following cultivars or lines were obtained from Leggett Farming Partnership, Nashville, NC: B94-24, Diane, Murasaki-29, O'Henry, and Porto Rico. Slips of 'Evangeline', 'Hernandez', and 'Japanese' were obtained from Bone Farms, Nashville, NC. Slips of 'Korean Purple' were obtained from Mapple Farm. Cuttings with two to three nodes were propagated from the slips and rooted for 2 weeks in 98-cell trays in a greenhouse starting on 31 May 2012. Greenhouse temperatures, growing media, and fertilization of cuttings were the same as in 2011 .

At planting, soil temperature in the field was $\approx 20{ }^{\circ} \mathrm{C}$ at a depth of $10 \mathrm{~cm}$ as measured with a soil thermometer. Rooted transplants were watered thoroughly and fertilized at planting with $0.25 \mathrm{~L}$ per plant of $2 \mathrm{~g} \cdot \mathrm{L}^{-1}$ 10N-22.9P-8.3K (Plant Products) water-soluble fertilizer that also contained $0.1 \% \mathrm{Fe}, 0.05 \% \mathrm{Cu}, 0.02 \%$ $\mathrm{B}, \quad 0.05 \% \mathrm{Mn}, \quad 0.05 \% \mathrm{Zn}$, and $0.0005 \%$ Mo. No additional fertilizer was applied because of high soil fertility. There was no additional irrigation in 2011. In 2012, plants were watered one additional time on 21 June as weather was hot and dry immediately after planting. The growing season of 2012 was warmer and much drier than in 2011 (Table 2).

In both years, cuttings were transplanted on 15 June (Table 2) 
with a vegetable transplanter (model 1600; Rain-Flo Irrigation, East Earl, PA). Spacing was $30 \mathrm{~cm}$ within the rows and $2 \mathrm{~m}$ between rows, with a plant population of 12 plants/plot and 16,667 plants/ha. Each plot measured $3.6 \times 2 \mathrm{~m}$ and was separated from the next plot by $1 \mathrm{~m}$ within the row. Guard rows of 'Beauregard' surrounded the experimental field. The experiment was laid out in a randomized complete block design with four replicates.

Weeding between the rows was done twice mechanically in late June and early July and two or three times by hand in late July and early August once sweetpotato vines had spread enough to prevent mechanical weeding.

Insect sample collection was done with sticky traps, pitfall traps, and bait traps. We installed yellow $23 \times$ $14 \mathrm{~cm}$ sticky traps (Pherocon $\mathrm{AM}^{\mathrm{TM}}$; Trécé Inc., Adair, OK) weekly starting on 19 July 2011 and 29 June 2012. They were attached to metal posts and placed $\approx 40 \mathrm{~cm}$ above the crop canopy. We placed four traps in the experimental field to detect potential pest insects present in the plots. The traps were removed each week and then stored in a freezer for later insect identification and counts. The total numbers of flea beetles and other species of leaf beetles (Chrysomelidae) captured on each trap were counted. As thrips (Thysanoptera) and aphids (Aphididae) were caught in very high numbers only the quantities trapped on one (for aphids) or three (for thrips) squares (out of 59), randomly chosen on each side of the traps, were counted. In 2011 , we placed potato (Solanum tuberosum) bait traps and corn (Zea mays) bait traps as well as pitfall traps (Allen, 2009) weekly in the soil to detect the presence of millipedes (Diplopoda) starting on 20 July. These were not used in 2012 as we detected no millipedes in 2011.

In 2011 , the foliage was cut manually with hedge trimmers $2 \mathrm{~d}$ before harvest and the storage roots were harvested by hand with the help of pitchforks. In 2012, we mowed the foliage (Table 2) with a flail mower, which also tore the remaining pieces of plastic mulch. The roots were harvested mechanically with a multipurpose digger (Willsie Equipment Sales, Thedford, ON, Canada) with a 66-cm-wide blade. We washed the roots before grading and weighing. Storage roots at least 1 inch in diameter were graded into three categories, grade no.1, grade no. 2, and cull (USDA, 2005); then counted and weighed. Marketable yield was the total of grade no. 1 and grade no. 2 yields and included roots 1.5 to 3.5 inches in diameter. We calculated average storage root weight by dividing total yield by total number of storage roots for each cultivar. All results were analyzed using the Proc GLM in SAS software (version 9.3; SAS Institute, Cary, NC). Blocks were considered random effects, whereas cultivars were considered fixed. Means separation was done using the least significant difference test when model and treatment effects were significant $(P<0.05)$.

To facilitate comparisons of temperatures from different years, daily GDD were calculated as follows: $\mathrm{GDD}=[($ maximum air temperature + minimum air temperature)/2] - base temperature, where the base temperature was $15.5^{\circ} \mathrm{C}$ (OMAFRA, 2010) or $60{ }^{\circ} \mathrm{F}$ (Villordon et al., 2009). If the average of the minimum and maximum air temperatures was below the base temperature on any given day, the number of GDD was set to 0 (McMaster and Wilhelm, 1997). Villordon et al. (2009) also suggested an alternative method for calculating GDD using only maximum temperatures: GDD = maximum air temperature - base temperature, where base temperature was $60^{\circ} \mathrm{F}$ and a ceiling temperature of $90^{\circ} \mathrm{F}$ was included so that temperatures exceeding $90{ }^{\circ} \mathrm{F}$ were considered as being the same as $90{ }^{\circ} \mathrm{F}$. If the maximum air temperature was below the base temperature, the number of GDD was set to 0. Cumulative GDD were the sums of daily GDD from planting date until harvest date (Table 2).

Temperature and precipitation data from Pierre-Elliot Trudeau Airport in Dorval, QC, Canada located $\approx 15 \mathrm{~km}$ east of the experimental site, were obtained from Environment Canada (2014) as data for Sainte-Anne-deBellevue were missing for part of 2011 .

The concentration of soluble solids in uncured storage roots was determined in 2012 based on the methodology of Grube (2007). Cubes of sweetpotato flesh, $\approx 1$ to $2 \mathrm{~cm}^{3}$, were cut from four different uncured storage roots of each of nine cultivars $\approx 3$ weeks after harvest.
These samples were frozen in plastic bags for $\approx 1$ week and then thawed. Juice was manually extracted and placed on a handheld refractometer (model ATC-le; Atago USA, Inc., Bellevue, WA) for a reading in percent soluble solids. Walter (1992) stated that handheld refractometers could give acceptable accuracy for estimating soluble solid concentrations in sweetpotato.

\section{Results and discussion}

In 2011, Beauregard had the highest total and marketable yield of the orange-fleshed cultivars we tested (Table 3). Only half of 'Ginseng Red's' total yield was marketable as many roots were malformed. Some storage roots may actually have been initiated in the plug trays before transplanting. It is likely that these storage roots became misshapen at that point. This suggests that it is important, especially with this cultivar, to not delay transplanting after fibrous roots are formed on cuttings. Bornt (2012) also noted the problem of crooked roots forming before transplanting rooted cuttings. The yellow-fleshed 'Georgia Jet' and GJ2010 had the highest total and marketable yields and were not significantly different from each other (Table 3). The average root weights of 'Beauregard' and the previous two cultivars were significantly higher than those of Ginseng Red and White Travis (Table 3). The whitefleshed cultivar White Travis produced more storage roots per plant than the other cultivars (except GJ2010), but many of these were small and/or crooked. At only $53 \mathrm{~g} /$ root, 'White Travis' had the smallest storage roots by far (Table 3).

In 2012, B94-24, Diane, Evangeline, Hernandez, and Beauregard were the orange-fleshed cultivars and lines with the highest marketable yields, ranging from 15.5 to $19.7 \mathrm{t} \cdot \mathrm{ha}^{-1}$ (Table 4 ). B9424 and 'Beauregard' had the heaviest storage roots, 275 and $330 \mathrm{~g}$, respectively. 'Covington' and 'Porto Rico' had the lowest marketable yields with only 9.2 and $7.1 \mathrm{t} \cdot \mathrm{ha}^{-1}$, respectively. 'Porto Rico' produced only 2.0 marketable sweetpotatoes per plant (Table 4) and some of the storage roots had sprouts at harvest. With most of the orange cultivars, $66 \%$ to $80 \%$ of the yield was marketable and $25 \%$ to $37 \%$ was grade no. 1. 'Porto Rico' was the worst with only $50 \%$ 
Table 3. Yields of five sweetpotato cultivars and selected lines grown with black plastic mulch in Sainte-Anne-de-Bellevue, QC, Canada in $2011(\mathrm{n}=\mathbf{4 8})$.

\begin{tabular}{|c|c|c|c|c|c|c|c|}
\hline Flesh color & $\begin{array}{c}\text { Cultivar } \\
\text { or selected } \\
\text { line } \\
\end{array}$ & $\begin{array}{c}\text { Total } \\
\text { yield } \\
\left(\mathrm{kg} \cdot \mathrm{ha}^{-1}\right)^{\mathrm{z}}\end{array}$ & $\begin{array}{c}\text { Marketable } \\
\text { yield } \\
\left(\mathbf{k g} \cdot \mathrm{ha}^{-1}\right) \\
\end{array}$ & $\begin{array}{c}\text { Yield } \\
\text { grade no. } 1^{\mathrm{y}} \\
\left(\mathrm{kg} \cdot \mathrm{ha}^{-1}\right)\end{array}$ & $\begin{array}{c}\text { Avg wt } \\
\text { of storage } \\
\text { roots }(\mathrm{g} / \text { root })^{\mathrm{z}}\end{array}$ & $\begin{array}{c}\text { Total storage } \\
\text { roots } \\
\text { (no./plant) }\end{array}$ & $\begin{array}{c}\text { Marketable } \\
\text { storage roots } \\
\text { (no./plant) }\end{array}$ \\
\hline Orange & Beauregard & $23,963 b^{x}$ & $18,771 \mathrm{~b}$ & $6,067 \mathrm{bc}$ & $173 \mathrm{a}$ & $8.4 \mathrm{c}$ & $5.3 \mathrm{~b}$ \\
\hline \multirow[t]{2}{*}{ Yellow } & Georgia Jet & 28,733 a & $25,121 \mathrm{a}$ & $10,404 \mathrm{a}$ & $200 \mathrm{a}$ & $8.7 \mathrm{bc}$ & $6.3 \mathrm{~b}$ \\
\hline & GJ2010 & $27,583 \mathrm{ab}$ & $25,492 \mathrm{a}$ & $7,938 \mathrm{ab}$ & $173 \mathrm{a}$ & $9.7 \mathrm{~b}$ & $6.9 \mathrm{ab}$ \\
\hline White & White Travis & $12,621 \mathrm{c}$ & $10,767 \mathrm{c}$ & $3,596 \mathrm{~d}$ & $53 \mathrm{c}$ & $14.3 \mathrm{a}$ & $8.6 \mathrm{a}$ \\
\hline
\end{tabular}

${ }^{\mathrm{z}} 1 \mathrm{~kg} \cdot \mathrm{ha}{ }^{-1}=0.8922 \mathrm{lb} /$ acre, $1 \mathrm{~g}=0.0353 \mathrm{oz}$.

yarketable yield and roots include all grade no. 1 and grade no. 2 sweetpotatoes, $1.5-3.5$ inches in diameter; 1 inch = $2.54 \mathrm{~cm}$.

${ }^{\mathrm{x}}$ Means within columns followed by the same letter are not significantly different at the 0.05 level according to the least significant difference test.

Table 4. Yields of 15 sweetpotato cultivars and selected lines grown with black plastic mulch in Sainte-Anne-de-Bellevue, QC, Canada in $2012(n=48)$.

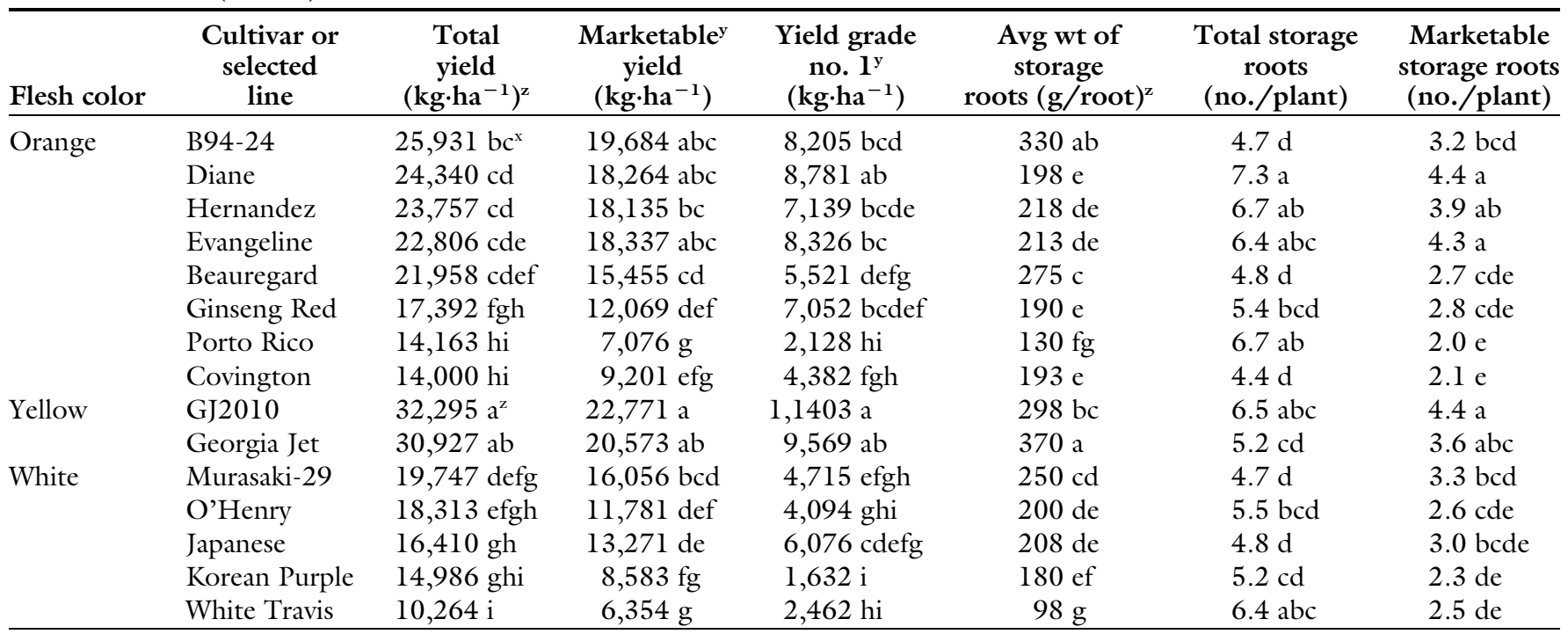

${ }^{\mathrm{z}} 1 \mathrm{~kg} \cdot \mathrm{ha}^{-1}=0.8922 \mathrm{lb} /$ acre, $1 \mathrm{~g}=0.0353 \mathrm{oz}$.

${ }^{y}$ Marketable yield and roots include all grade no. 1 and grade no. 2 sweetpotatoes, $1.5-3.5$ inches in diameter; 1 inch $=2.54 \mathrm{~cm}$.

${ }^{\mathrm{x}}$ Means within columns followed by the same letter are not significantly different at the 0.05 level according to the least significant difference test.

marketable yield and $15 \%$ grade no. 1 . 'Ginseng Red', at $41 \%$ grade no. 1 , was the best. This was very different from 2011 , where only 17\% of 'Ginseng Red' was graded no. 1. In 2012, the transplants were $\approx 1$ week younger than in 2011 and therefore may not have initiated any storage roots before transplanting in the field. The grade no. 1 yields of the orange-fleshed B94-24, 'Hernandez', 'Evangeline', and 'Ginseng Red' did not differ significantly from those of 'Georgia Jet' (Table 4). The yellow-fleshed Georgia Jet and GJ2010 had the highest total yields of all cultivars tested but many roots were cracked, crooked, or oversized. Among the white-fleshed cultivars, Murasaki-29,Japanese, and O'Henry had the highest marketable yields with 16.1, 13.2, and $11.8 \mathrm{t} \cdot \mathrm{ha}^{-1}$, respectively (Table 4 ). There was much skin damage to 'Japanese' during harvest. Murasaki-29 had heavier roots than the other white cultivars although not significantly so compared with Japanese and O'Henry. As in 2011, White Travis had the lowest yield and the lightest storage roots: this cultivar may require a much longer growing season. The quality of 'Korean Purple' was low: only $11 \%$ of its yield was grade no. 1 compared with $24 \%$ to $37 \%$ for the other white cultivars. Many of its storage roots broke during harvest.

There were much smaller differences among cultivars in the number of storage roots per plant in 2012 than in 2011. In 2011, numbers ranged from 6.1 roots per plant for 'Ginseng Red' to 14.3 for 'White Travis', whereas in 2012, they ranged from 4.4 for 'Covington' to 7.3 for 'Diane'. In 2012, the number of marketable roots per plant for seven of the cultivars (Covington, Korean Purple, White Travis, O'Henry,
Beauregard, Ginseng Red, and Japanese) was not significantly higher than that of the worst cultivar, White Travis (Table 4).

With some cultivars, average root weights were higher in 2012 than in 2011 , but the number of roots per plant was lower (Tables 3 and 4). Drought stress to the young transplants soon after planting in 2012 may have limited the initiation of storage roots. By initiating fewer storage roots per plant, the resulting sweetpotatoes grew to a heavier final weight. In all years, the main reasons for culling storage roots were small size and poor shape. In addition, growth cracks were frequent in 'Georgia Jet' and GJ2010.

In 2013, we carried out a nonreplicated trial of eight of the best cultivars and lines (Beauregard, B9424, Diane, Evangeline, Hernandez, Georgia Jet, GJ2010, and Murasaki-29) 
from the previous years. The best orange-fleshed cultivar was Evangeline with a total yield of $17.3 \mathrm{t} \cdot \mathrm{ha}^{-1}$ but only $52 \%$ was marketable (data not shown). The marketable yields of 'Beauregard' (5.8 t.ha ${ }^{-1}$ ) and B94-24 $\left(5.6 \mathrm{t} \cdot \mathrm{ha}^{-1}\right)$ were similar to each other but much lower than in 2012 . 'Diane' and 'Hernandez' had the lowest marketable yields (2.4 and $2.1 \mathrm{t} \cdot \mathrm{ha}^{-1}$, respectively) and the smallest roots. 'Georgia Jet' produced the highest total yield (almost $20 \mathrm{t} \cdot \mathrm{ha}^{-1}$ ) and the heaviest storage roots $(435 \mathrm{~g} /$ root $)$, but less than a quarter were marketable. A large proportion of sweetpotatoes were crooked, had growth cracks or were oversized (data not shown). The lower yields observed in 2013 were probably related to cooler temperatures. There were only 478 GDD accumulated in 2013 compared with 558 GDD in 2011 and 584 GDD in 2012 (Table 2). Total rainfall for the 2013 cropping season was almost $400 \mathrm{~mm}$, higher than in 2012 but less than in 2011 (Table 2).

Many of our results were similar to those reported by other authors. Overall, our best marketable yields in 2011 and 2012 ( 18 to $25 \mathrm{t} \cdot \mathrm{ha}^{-1}$ ) were comparable to the average yields (2l to $\left.23 \mathrm{t} \cdot \mathrm{ha}^{-1}\right)$ in the United States (Food and Agriculture Organization of the United Nations, 2013). 'Beauregard' and 'Evangeline' both had good and similar yields, as has also been reported by Nair et al. (2012) in Iowa and in a multisite summary compiled by the National Sweetpotato Collaborators Group (2012). In Iowa (Lawson and Hannan, 2010), 'Porto Rico' produced many small roots and a high proportion $(43 \%)$ of culls. Jackson and Harrison (2013), Sideman (2013), and Goldy and Wendzel (2008) also noted low yields with 'Porto Rico' although it is not clear if the same line of 'Porto Rico' was used in all trials. As in our trials, Sideman (2013) in New Hampshire, Bornt (2012) in New York State and Lawson and Hannan (2010) in Iowa found that 'Georgia Jet' had high total yields, but a high proportion of nonmarketable sweetpotatoes, often because of growth cracks.

There were a few important differences between our results and those of other workers. The most notable is the poor performance of 'Covington' in our trials (Table 4).
Many authors, including those working in regions farther north than traditional sweetpotato-growing areas, have obtained good marketable yields with 'Covington', generally similar to 'Beauregard'. This was noted by Sideman (2013) in New Hampshire, Bornt (2012) in New York State, and Filotas (2012) in Ontario although the latter obtained a much lower proportion of grade no. 1 roots with 'Covington' than with 'Beauregard'. It is possible that our growing season is simply too short and/or too cool for 'Covington' to fully exhibit its potential. 'Covington' may require 5 to $10 \mathrm{~d}$ more than 'Beauregard' to reach maturity even in the warm conditions of North Carolina (Yencho et al., 2008). Villordon et al. (2009) suggested a minimum of 2600 GDD (using their maximum temperature method) before harvesting sweetpotato, whereas we only reached $\approx 1900$ to 2000 GDD (Table 2). Also our low N fertilization rates may have limited yields in certain cultivars. 'Covington' may require more $\mathrm{N}$ than 'Beauregard' (OMAFRA, 2010; Yencho et al., 2008). La Bonte et al. (2008a) noted that 'Murasaki-29' had lower yields and matured slightly later than 'Beauregard'. However, in our 2012 trial, both total and marketable yields were similar for these two cultivars.

The test for soluble solids showed three distinct groups of cultivars (Table 5). 'Covington' and 'Evangeline' had the highest concentration of soluble solids ( $13 \%$ to $13.6 \%$ soluble solids). 'Hernandez' had an intermediate reading of $12 \%$ soluble solids. The other six cultivars and lines tested (Georgia Jet, Beauregard, Ginseng Red, B94-24, O'Henry, and Diane) had a lower soluble solid concentration ranging between $9.6 \%$ and $10 \%$ soluble solids. Evangeline has been noted as an especially sweet-tasting cultivar with higher sucrose content than 'Beauregard' (La Bonte et al., 2008b). Sideman (2013) and Yencho et al. (2008) found that 'Covington' had slightly higher percent soluble solids than 'Beauregard'. Sideman (2013) noted that percent soluble solids were correlated with flavor. For example, 'O'Henry' rated low in tasting tests and, as in our test, had low soluble solids.

On 25 July 2012, an informal visual assessment of vine vigor, based on groundcoverage, found that Georgia Jet, GJ2010, Murasaki-29, and Japanese were the most vigorous cultivars, followed closely by Diane. 'White Travis', B94-24, 'Hernandez', and 'Evangeline' had medium vigor followed by 'Beauregard' and 'Porto Rico'. 'O'Henry', 'Covington', and 'Ginseng Red' were the least vigorous. La Bonte et al. (1999) noted low vine vigor in 'Beauregard' and its poor competitiveness with weeds. Vigorous sweetpotato vines may be advantageous, particularly in organic systems, as they may compete more effectively with weeds (Treadwell et al., 2007).

The most abundant weeds observed in 2011 were lamb's quarters (Chenopodium album), red root pigweed (Amaranthus retroflexus), barnyard grass (Echinochloa crusgalli), and field bindweed (Convolvulus arvensis). In 2012, in addition to the previous species, purslane (Portulaca oleracea) and large crab grass (Digitaria sanguinalis) were observed. Removal of field bindweed was particularly problematic as it often became entwined with sweetpotato vines.

No diseases were observed in the field. Because sweetpotato is a new and minor crop in our region, pathogen populations may be quite low. However, postharvest storage soft rots appeared on some sweetpotatoes. Although we made no formal evaluation of storage rots, there did seem to be some variability among cultivars. 'Ginseng Red' had almost no storage rot, whereas 'Diane' and 'Georgia Jet' appeared to be more susceptible. Bohac et al. (2002) reported that the latter two cultivars were disease susceptible although did not specify to which pathogens. Many of the storage roots of 'Diane' had large lenticels in 2012. Lewthwaite et al. (2011) noted that some sweetpotato pathogens can enter storage roots via lenticels.

The main pests trapped in the fields were thrips, aphids, flea beetles, and some other leaf beetle species. Thrips and aphids were not identified to species. Thrips were the most abundant pest detected, followed by aphids (Fig. IA and B). The numbers trapped per week increased throughout the growing season, then declined in September and October, perhaps because of cool weather at that time. Some redheaded flea 
beetles (Systena frontalis) were also observed on the sticky traps in both 2011 and 2012. Some tarnished plant bugs (Lygus lineolaris) were trapped in 2011. Weekly visual inspection of plants, starting at planting, showed no obvious symptoms of pest damage except for some small holes on leaves

Table 5. Soluble solid concentration of nine sweetpotato cultivars and selected lines grown in Sainte-Annede-Bellevue, QC, Canada in 2012 were measured with a handheld refractometer $(n=4)$.

\begin{tabular}{lc}
\hline $\begin{array}{l}\text { Cultivar or } \\
\text { selected line }\end{array}$ & $\begin{array}{c}\text { Soluble solids } \\
\text { concn }(\%)\end{array}$ \\
\hline Covington & $13.6 \mathrm{a}^{\mathrm{z}}$ \\
Evangeline & $13.0 \mathrm{a}$ \\
Hernandez & $12.0 \mathrm{~b}$ \\
Georgia Jet & $10.0 \mathrm{c}$ \\
Beauregard & $9.9 \mathrm{c}$ \\
Ginseng Red & $9.8 \mathrm{c}$ \\
B94-24 & $9.7 \mathrm{c}$ \\
O'Henry & $9.7 \mathrm{c}$ \\
Diane & $9.6 \mathrm{c}$ \\
\hline
\end{tabular}

${ }^{2}$ Means within columns followed by the same letter are not significantly different at the 0.05 level according to the least significant difference test.
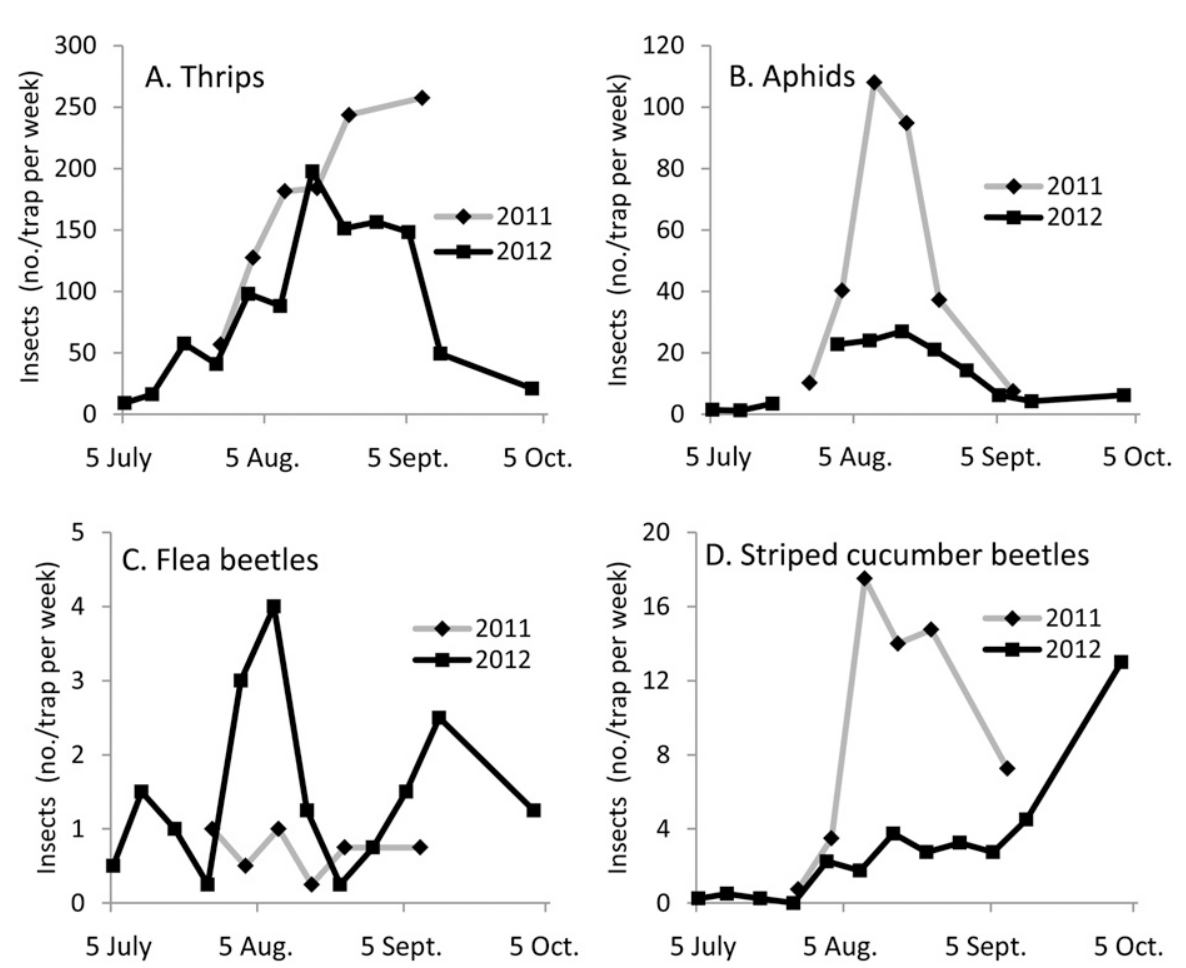

Fig. 1. Numbers of selected pest insects (means of four samples) trapped weekly on yellow sticky cards placed in sweetpotato experimental plots in Sainte-Anne-deBellevue, QC, Canada in 2011 and 2012: the total numbers of all species of (A) thrips, (B) aphids, and (C) flea beetles are reported. Of the various species of leaf beetles, only the numbers of (C) flea beetles and (D) striped cucumber beetles are reported here.

possibly caused by flea beetles, which were occasionally observed on foliage even though the number of flea beetles trapped in the field was low (Fig. 1C). Moderate numbers of striped cucumber beetles (Acalymma vittatum) were trapped (Fig. 1D) in addition to very low numbers (usually less than 3 per card per week) of the following species: northern corn root worm (Diabrotica barberi), spotted cucumber beetle (Diabrotica undecimpunctata howardi), and western corn root worm (Diabrotica virgifera virgifera). However, the presence of these pests may have been incidental as there were nearby plots of melon (Cucumis melo) and cucumber (Cucumis sativus), potential hosts of the striped cucumber beetle and the other previously mentioned leaf beetles.

Susceptibility to pests may vary with cultivar. Hernandez et al. (1981) reported that 'Travis' was resistant to the sweetpotato flea beetle (Chaetocenema confinis), but susceptible to the banded cucumber beetle (Diabrotica balteata). Yencho et al. (2008) found that 'Covington' was less affected by

Hortlechnology $\cdot$ December 2015 25(6) sweetpotato flea beetle than 'Beauregard'. However, in our trials no obvious differences between cultivars were observed. Also, the sweetpotato flea beetle was not observed or captured in our trials. Wireworms (Elateridae) can be a frequent pest in sweetpotato (Grube, 2009; Jackson and Harrison, 2013). Jackson and Harrison (2013) evaluated the resistance of several sweetpotato cultivars to the wireworms, Diabrotica sp., Systena sp. (WDS) pest complex. According to their findings, several of the cultivars included in our trial were highly susceptible to damage by the WDS complex, in particular Covington, Evangeline, O'Henry, Hernandez, Beauregard, and Diane. 'Murasaki-29' on the other hand showed very little susceptibility. However, very little root damage was observed on any cultivar in our trials. As sweetpotato is rarely grown in our region, insect pest populations may have been very low even though no insecticides were applied.

The following conclusions must be viewed with caution given the limited scope of our trial. The best cultivars in our trials gave yields comparable to those in traditional sweetpotato production areas located much farther south even though the number of accumulated GDD was much lower than what Villordon et al. (2009) suggested. Thus, growing this crop with plastic mulch and rooted cuttings but without pesticides may be viable in our region. The orange-fleshed 'Beauregard', B94-24, and 'Evangeline' appeared promising and may warrant further testing. 'Evangeline' had the added advantage of high sugar content. The other orange cultivars had variable or poor performance. 'Diane' and 'Hernandez' did well in 2012 but poorly in 2013 , which was a cooler year. 'Covington' gave poor yields in 2012. The marketable yields of the two heirloom cultivars, Ginseng Red and Porto Rico, were moderate to poor with many roots too small to be marketable, especially with the latter. 'Georgia Jet' and GJ2010 had high yields but also many culls, mainly because of deformities and growth cracks. Also, the yellow-fleshed selected lines we grew may be less acceptable to consumers than the orange-fleshed sweetpotatoes generally preferred by North Americans 
(Leksrisompong et al., 2012). Of the three "Asian" cultivars (purple skins, white flesh) tested, Murasaki-29 performed best and should perhaps be tested further. The white-fleshed 'O'Henry' showed some promise, but results must be viewed with caution as it was only tested for 1 year. 'White Travis' had low yields of small storage roots in both 2011 and 2012 and cannot be recommended for our growing conditions.

Few pest problems or diseases, other than postharvest soft rots, were observed suggesting that in our region sweetpotato production has potential for organic farms or at least pesticide-free growing systems. However, pest populations could increase if this crop was widely adopted by local farmers. Although it may be difficult for northern growers to compete with sweetpotato production in areas with warmer, longer growing seasons, they may be able to supply niche markets where there is a demand for locally grown or organic vegetables.

\section{Literature cited}

Allen, J. 2009. Millipedes in carrots and sweet potatoes. Ontario Ministry Agr. Food Rural Affairs Agdex 258/611. 19 Apr. 2015. <http://www.omafra.gov. on.ca/english/crops/facts/09-009w.htm>.

Bohac, J.R., D.M. Jackson, J.D. Mueller, and P.D. Dukes. 2002. 'Ruddy': A multiple-pest-resistant sweetpotato. HortScience 37:993-994.

Bornt, C. 2012. Improving the yield and quality of sweet potatoes grown in New York, 2012 Final report. 4 Mar. 2015. <http://mysare.sare.org/mySARE/ ProjectReport.aspx? do = viewRept\&pn = LNE10-292\&y $=2012 \& \mathrm{t}=0>$.

Bovell-Benjamin, A.C. 2007. Sweet potato: A review of its past, present, and future role in human nutrition. Adv. Food Nutr. Res. 52:1-59.

Eguchi, T., M. Kitano, and H. Eguchi. 1994. Effect of root temperature on sink strength of tuberous root in sweet potato plants ( $\mathrm{Ipo}^{-}$ moea batatas Lam.). Biotronics 23:75-80.

Environment Canada. 2014. Climate data on-line. 25 Apr. 2015. <http://www. climate.weatheroffice.gc.ca/>.

Food and Agriculture Organization of the United Nations. 2013. FAOSTAT: Production quantities by country. 5 Feb. 2015. <http://faostat.fao.org/site/ $567 /$ DesktopDefault.aspx? PageID = 567 \#ancor>.
Filotas, M. 2012. Sweet potato varieties for Ontario. 13 Apr. 2015. <http:// www.farmersmarketsontario.com/ DocMgmt $\%$ CPublications\%5CON\% 20 Organic $\% 20$ Newsletters $\% 5 C O N_{-}$ Organic_May_2012.pdf $>$.

Goldy, R. and V. Wendzel. 2008. Evaluation of ten sweet potato cultivars in southwest Michigan. 10 May 2015. $<$ https://ag.purdue.edu/hla/fruitveg/ MidWest\%20Trial\%20Reports/09_Sweet \%20potato_01_Goldy.pdf>.

Grube, B. 2007. Sweetpotatoes in northern New England. 15 Apr. 2015. $<$ http://www.newenglandvfc.org/pdf proceedings/SweetPotatoesNE.pdf>.

Grube, B. 2009. Growing sweet potatoes in New Hampshire. 13 May 2015. <http:// mysare.sare.org/mySARE/assocfiles/ 901037sweetpot.pdf>.

Harmon, S.A. 1974. Georgia Jet: An early, high yielding high quality sweet potato cultivar for Georgia. Univ. Georgia, College Agr. Expt. Sta. Res. Rpt. 193.

Hernandez, T.P., R.J. Constantin, H.L. Hammett, W.J. Martin, C.A. Clark, and L. Rolston. 1981. 'Travis' sweet potato. HortScience 16:574.

Hochmuth, G.J. and J.C. Howell. 1983. Effect of black plastic mulch and raised beds on sweet potato growth and root yield in a northern region. HortScience 18:467-468.

Jackson, D.M. and H.F. Harrison, Jr. 2013. Insect resistance in traditional and heirloom sweetpotato varieties. J. Econ. Entomol. 106:1456-1462.

La Bonte, D.R., H.F. Harrison, and C.E. Motsenbocker. 1999. Sweetpotato clone tolerance to weed interference. HortScience 34:229-232.

La Bonte, D.R., W.A. Mulkey, C.A. Clark, L.H. Rolston, J.M. Cannon, P.W. Wilson, and P.C. St Amand. 1992. 'Hernandez' sweetpotato. HortScience 27:377.

La Bonte, D.R., A.Q. Villordon, C.A. Clark, P.W. Wilson, and C.S. Stoddard. 2008a. 'Murasaki-29' sweetpotato. HortScience 43: 1895-1896.

La Bonte, D.R., P.W. Wilson, A.Q. Villordon, and C.A. Clark. 2008b. 'Evangeline' sweetpotato. HortScience 43:258-259.

Land Food People Foundation. 2014. Land Food People Foundation home page. 26 Jan. 2015 . <http:// landfoodpeople.ca/about $>$.

Lawson, V. and J. Hannan. 2012. Sweet potato cultivar trial, 2010. 10 May 2015. <https://www2.ag.purdue.edu/hla/ fruitveg/MidWest\%20Trial\%20Reports/
8-1_Lawson_Sweet\%20Potato_Cultivar\% 20trial_LR.pdf>.

Lebot, V. 2009. Tropical root and tuber crops: Cassava, sweet potato, yams and aroids. CAB Intl., Wallingford, UK.

Leksrisompong, P.P., M.E. Whitson, V.D. Truong, and M.A. Drake. 2012. Sensory attributes and consumer acceptance of sweet potato cultivars with varying flesh colors. J. Sens. Stud. 27:59-69.

Lewthwaite, S.L., P.J. Wright, and C.M. Triggs. 2011. Sweetpotato cultivar susceptibility to infection by Ceratocystis fimbriata. N.Z. Plant Protection 64:1-6.

McMaster, G.S. and W.W. Wilhelm. 1997. Growing degree-days: One equation, two interpretations. Agr. For. Meteorol. 87:291-300.

Nair, A., B. Bergaum, and M. Bilenky. 2012. Sweet potato cultivar trial. 13 Dec. 2014. <http://farms.ag.iastate.edu/sites/ default/files/SweetPotatoCultivar.pdf>.

National Sweetpotato Collaborators Group. 2012. National Sweetpotato Collaborators Group progress rpt. 2011. K. Pecota (ed.). National Sweetpotato Collaborators Group, Birmingham, AL.

Novak, B., I. Žutić, N. Toth, and N. Dobričević. 2007. Sweet potato [Ipomoea batatas (L.) Lam] yield influenced by seedlings and mulching. Agr. Conspectus Scientificus 72:357-359.

Ontario Ministry of Agriculture, Food and Rural Affairs (OMAFRA). 2010. Vegetable production recommendations 2010-2011. Ontario Ministry Agr. Food Rural Affairs Publ. 363.

Pope, D.T. and M.W. Hoover. 1966. N.C. Porto Rico 198: An improved strain of the Porto Rico sweet potato variety. North Carolina Agr. Expt. Sta. Bul. 429.

Rolston, L.H., C.A. Clark, J.M. Cannon, W.M. Randle, E.G. Riley, P.W. Wilson, and M.L. Robbins. 1987. 'Beauregard' sweetpotato. HortScience 22:1338-1339.

Sand Hill Preservation Center. 2015. Sweet potato varieties. 31 July 2015 . <http:// www.sandhillpreservation.com/catalog/ sweet_potatoes.html>.

Sideman, B. 2013. Varieties, cultural practices, and post-harvest management of sweet potatoes for New England. 10 June 2014. <http://www.newenglandvfc.org/ 2013_conference/proceedings2013/ Sideman Sweetpotato Varieties 2013.pdf>.

Statistics Canada. 2014. Table002-001, Food available in Canada. 17 Apr. 2015. <http://www5.statcan.gc.ca/cansim/ a 05 ? l a $\mathrm{g}=\mathrm{e} n \mathrm{~g} \& \mathrm{id}=0020011 \&$ pattern $=0020011 \&$ search TypeByValue $=1 \&$ $\mathrm{p} 2=35>$. 
Treadwell, D.D., N.G. Creamer, J.R. Schultheis, and G.D. Hoyt. 2007. Cover crop management affects weeds and yield in organically managed sweetpotato systems. Weed Technol. 21:1039-1048.

U.S. Department of Agriculture (USDA). 2005. United States standards for grades of sweet potatoes. 10 July 2011 . <http:// www.ams.usda.gov/AMSv1.0/getfile? $\mathrm{dDocName}=$ STELPRDC5050330 $>$.

U.S. Department of Agriculture (USDA). 2011 a. U.S. sweetpotato statistics. Economic Research Service. 16 June 2014. <http://usda.mannlib.cornell.edu/ MannUsda/viewDocumentInfo.do? documentID $=1492>$.
U.S. Department of Agriculture (USDA). 2011 b. Vegetable and melons yearbook. Economic Research Service. 16 June 2014. $<$ http://usda.mannlib.cornell.edu/ MannUsda/viewDocumentInfo.do? documentID $=1212>$.

Villordon, A., C. Clark, D. Ferrin, and D. LaBonte. 2009. Using growing degree days, agrometeorological variables, linear regression, and data mining methods to help improve prediction of sweetpotato harvest date in Louisiana. HortTechnology 19:133-144.

Walter, W.M. 1992. Use of refractive index to monitor changes in sugar content of stored sweetpotatoes. HortScience 27:333-335.

Yencho, G.C., K.V. Pecota, J.R. Schultheis, Z.P. VanEsbroeck, G.J. Holmes, B.E. Little, A.C. Thornton, and V.D. Truong. 2008. 'Covington' sweetpotato. HortScience 43:1911-1914.

Zvalo, V., W. Kalt, J. Shi, S.A.E. Fillmore, and J. Owen. 2012. Sweet potatoes (Ipomoea batatas) of diverse colours grown in Atlantic Canada. 15 May 2015. <http:// www.researchgate.net/profile/Josee Owen/publication/273456502_Sweet potatoes_(Ipomoea_batatas)_of_diverse colours_grown_in_Atlantic_Canada/ links/5502fde80cf231de076fcc05.pdf>. 